\title{
Adiponectin inhibits macrophage tissue factor, a key trigger of thrombosis in disrupted atherosclerotic plaques
}

\section{Citation}

Okamoto, Yoshihisa, So Ishii, Kevin Croce, Harumi Katsumata, Makoto Fukushima, Shinji Kihara, Peter Libby, and Shiro Minami. 2013. "Adiponectin Inhibits Macrophage Tissue Factor, a Key Trigger of Thrombosis in Disrupted Atherosclerotic Plaques." Atherosclerosis 226 (2) (February): 373-377. doi:10.1016/j.atherosclerosis.2012.12.012.

\section{Published Version}

doi:10.1016/j.atherosclerosis.2012.12.012

\section{Permanent link}

http://nrs.harvard.edu/urn-3:HUL.InstRepos:32605321

\section{Terms of Use}

This article was downloaded from Harvard University's DASH repository, and is made available under the terms and conditions applicable to Other Posted Material, as set forth at http:// nrs.harvard.edu/urn-3:HUL.InstRepos:dash.current.terms-of-use\#LAA

\section{Share Your Story}

The Harvard community has made this article openly available.

Please share how this access benefits you. Submit a story.

Accessibility 


\title{
Adiponectin inhibits macrophage tissue factor, a key trigger of thrombosis in disrupted atherosclerotic plaques
}

\author{
Yoshihisa Okamoto ${ }^{1,2}$, So Ishii ${ }^{1}$, Kevin Croce $^{3}$, Harumi Katsumata ${ }^{1}$, Makoto Fukushima ${ }^{1}$, \\ Shinji Kihara ${ }^{4}$, Peter Libby ${ }^{3}$, and Shiro Minami ${ }^{1,2}$ \\ ${ }^{1}$ Department of Bioregulation, Nippon Medical School, Kawasaki, Kanagawa, Japan \\ 2Division of Endocrinology, Diabetology and Atherosclerosis Medicine, Nippon Medical School \\ Musashi-kosugi Hospital, Kawasaki, Kanagawa, Japan \\ 3Division of Cardiovascular Medicine, Brigham and Women's Hospital, Harvard Medical School, \\ Boston, Massachusetts, USA \\ ${ }^{4}$ Department of Biomedical Informatics, Osaka University, Suita, Osaka, Japan
}

\begin{abstract}
Objective-Adiponectin (APN) is an adipocytokine with anti-atherogenic and anti-inflammatory properties. Hypoadiponectinemia may associate with increased risk for coronary artery disease (CAD) and acute coronary syndrome (ACS). Tissue factor (TF) initiates thrombus formation and facilitates luminal occlusion after plaque rupture, a common cause of fatal ACS. This study tested the hypothesis that APN influences TF expression by macrophages (MФ), inflammatory cells found in atheromatous plaques.
\end{abstract}

Methods-Human monocyte-derived MФ or RAW 264.7 cells transfected with TF promoter construct, pretreated with a physiological range of recombinant APN $(1-10 \mu \mathrm{g} / \mathrm{ml})$, received LPS stimulation. TF mRNA and protein levels were quantified by real-time RT-PCR and ELISA. TF pro-coagulant activity was evaluated by one-step clotting assay. TF promoter activity was determined by a dual-luciferase reporter assay. Immunoblot analyses assessed intracellular signaling pathways.

Results-APN treatment suppressed TF mRNA expression and protein production in LPSstimulated human MФ, compared to vehicle controls. APN treatment also significantly reduced TF pro-coagulant activity in lysates of LPS-stimulated human MФ, compared to vehicle controls. Moreover, APN suppressed TF promoter activity in LPS-stimulated MФ compared to controls. APN suppressed phosphorylation and degradation of I $k B-a$ in LPS-stimulated МФ.

Conclusions-APN reduces thrombogenic potential of MФ by inhibiting TF expression and activity. These observations provide a potential mechanistic link between low APN levels and the thrombotic complications of atherosclerosis.

\section{Keywords}

adiponectin; tissue factor; macrophage; atherothrombosis

(C) 2012 Elsevier Ireland Ltd. All rights reserved.

Corresponding Author: Yoshihisa Okamoto, M.D., Ph.D., Department of Bioregulation, Nippon Medical School, 1-396 Kosugimachi, Nakahara-ku, Kawasaki, Kanagawa, 211-8533, Japan, TEL: +81-44-733-2784, FAX: +81-44-733-4613, yokamoto@ nms.ac.jp.

Publisher's Disclaimer: This is a PDF file of an unedited manuscript that has been accepted for publication. As a service to our customers we are providing this early version of the manuscript. The manuscript will undergo copyediting, typesetting, and review of the resulting proof before it is published in its final citable form. Please note that during the production process errors may be discovered which could affect the content, and all legal disclaimers that apply to the journal pertain. 


\section{Introduction}

The common cluster of components that comprise the "metabolic syndrome" — including excess visceral fat accumulation, dyslipidemia, impaired glucose tolerance, and hypertension - associate with inflammation, and contribute to an increased risk of developing cardiovascular disease ${ }^{1}$. In patients with coronary artery disease (CAD), atherosclerotic plaque expansion results in progressive luminal obstruction that reduces blood flow and causes tissue ischemia. In contrast to progressive vessel narrowing from stable coronary stenosis, ischemic complications of atherosclerosis frequently occur when non-obstructive atherosclerotic plaques with thin fibrous caps undergo plaque rupture that results in sudden arterial thrombosis. ${ }^{2}$ Inflammation contributes to fibrous cap thinning and increases the risk of plaque rupture and ischemic atherothrombotic complications.

Adiponectin (APN), an adipose-specific secretory protein (adipocytokine), has anti-diabetic, anti-atherogenic, and anti-inflammatory properties ${ }^{3}$. Many studies have correlated reduced APN levels in plasma (hypoadiponectinemia) with CAD and with increased risk of cardiovascular events independent of traditional risk factors ${ }^{4-10}$. Some experimental studies, but not all, have shown that APN reduces atherosclerosis by suppressing atherogenic processes within the blood vessel wall ${ }^{4,11-16}$.

Patients with acute coronary syndromes (ACS) have reduced plasma APN compared to patients with stable $C A D^{17}, 18$. In addition, Nakagawa et al. recently reported that nocturnal dysregulation of APN may contribute to ACS in patients with excess visceral fat ${ }^{19}$.

Tissue factor (TF; also known as coagulation factor III or tissue thromboplastin) triggers blood coagulation. Upon binding to factor VIIa, the TF/VIIIa complex converts factor X into active proteinase factor $\mathrm{Xa}$ - which activates thrombin. Macrophages (MФ) and other vascular endothelial cells within atheroma express $\mathrm{TF}^{20}$. In undisrupted plaques, TF resides within the atheroma, sequestered from luminal blood. Plaque rupture exposes TF within the atheroma to blood, activating the clotting cascade ${ }^{20}$. Even when plaque rupture and thrombosis do not cause arterial occlusion, mural fibrin and platelet deposition likely promote plaque progression and arterial stenosis. We previously demonstrated by microarray screening that APN inhibits the expression of LPS-inducible TF in human MФ. ${ }^{15}$ The current study tested the hypothesis that APN directly regulates MФ TF expression.

\section{Materials and Methods}

\subsection{Cell culture}

Human monocytes/M $M$ were prepared as reported ${ }^{15}$. Differentiated $\mathrm{M} \Phi$ (Day 10) were incubated in M199 medium containing 1\% human serum, with or without recombinant APN, for 24 hours. MФ then were stimulated with $5 \mathrm{ng} / \mathrm{ml}$ of LPS for 6 hours or 15 minutes to analyze TF gene/protein expression (real-time quantitative RT-PCR, ELISA, and one-step clotting assay) or intracellular signaling (immunoblot analysis), respectively. RAW264.7 cells (ATCC, Manassas, VA, USA) were maintained per the supplier's instructions and used for luciferase reporter assay, as described below.

\subsection{Real-time quantitative $R T-P C R$}

After 6 hours of LPS treatment, total RNA from treated human M $\Phi$ were isolated by RNeasy micro kit (QIAGEN, Hilden, Germany). DNase I-treated total RNA was reversetranscribed, and real-time quantitative PCR with cDNA was performed on an iCycler iQ Real-Time PCR Detection System using SYBR Green I (Bio-Rad, Hercules, CA, USA). GAPDH was used as a reference mRNA to adjust the loading dispersion between samples. 
The sequence of sense primers and anti-sense primers was: human tissue factor, 5'-

GCCAGGAGAAAGGGGAAT-3' and 5'-CAGTGCAATATAGCATTTGCAGTAGC-3', human glyceraldehyde-3-phosphate dehydrogenase (GAPDH), 5'-

CAATGACCCCTTCATTGACCTC-3' and 5'-AGCATCGCCCCACTTGATT-3'.

\subsection{Cell Lysates of Monocytes/MФ and TF ELISA}

Monocytes/M $\mathrm{M}$ were disrupted by repeated freeze-thaw cycles or sonication, and TF was extracted with a buffer of Tris Buffered Saline (50 mM Tris, $100 \mathrm{mM} \mathrm{NaCl}, \mathrm{pH} 7.4)$ containing $0.1 \%$ Triton $\mathrm{X}-100$. Extraction was performed for 18 hours at $2^{\circ}-8^{\circ} \mathrm{C}$, and the lysed cells were centrifuged to remove cell debris. Cell lysates were stored at $-70^{\circ} \mathrm{C}$ until they were assayed. $2 \mu \mathrm{g}$ of the cell lysate were used to assay tissue factor protein with IMUBIND Tissue Factor ELISA Kit (American Diagnostica Inc, Stamford, CT, USA).

\subsection{Cell Transfection and Measurement of Luciferase Activity}

A human TF promoter fragment (from -278) subcloned into the firefly luciferase reporter vector, pGL2-Basic (TF -278), was obtained from Addgene (Cambridge, MA, USA) ${ }^{21,} 22$. TF-278 was transfected into RAW264.7 cells with lipofectamine LTX (Life Technologies, Grand Island, NY, USA), according to the manufacturer's protocol. Equivalent transcriptional efficacy was confirmed by co-transfecting the renilla luciferase control vector, pRL-SV40 (Promega, Madison, WI, USA). After transfection, cells were incubated for 24 hours in DMEM supplemented with $10 \%$ fetal bovine serum. Then, cells were treated with adiponectin for 24 hours, followed by 6 hours of stimulation with or without LPS (5 ng/ $\mathrm{ml})$. Luciferase activity in the cell lysate was measured with a dual luciferase assay kit (Promega) and a luminometer (Promega).

\subsection{One-Step Clotting Assay for Measuring Tissue Factor Activity}

To assess TF activity in MФ cell lysates, clotting assay was performed as reported previously ${ }^{23}$. Briefly, 50- $\mu$ l lysates containing $20 \mathrm{ng}$ of MФ cell protein, after 6 hours of LPS stimulation, were applied to each well in a 96-well plate, after which $50 \mu \mathrm{lnormal}$ pooled plasma (George King Bio-Medical Inc, Overland Park, KS, USA) was added. After incubation for 2 minutes at $37^{\circ} \mathrm{C}, 50 \mu \mathrm{l}$ of pre-warmed $25-\mathrm{nM}$ calcium chloride $(\mathrm{CaCl} 2)$ was added. Well absorbance (a surrogate measure for coagulation/fibrin formation) was read by a plate reader at $405 \mathrm{~nm}$ with kinetic mode (Spectra Max Plus 384, Molecular Devices, Sunnyvale, CA, USA) every 60 seconds for 180 minutes at $37^{\circ} \mathrm{C}$. "Clot initiation time" was determined as the time at which absorbance began to increase continuously. "Half-max time" was determined as the time at which the absorbance reading was half the difference between initial and maximum absorbance.

\subsection{Immunoblot analysis}

Immunoblot analyses with whole-cell lysates of $\mathrm{M} \Phi(20 \mu \mathrm{g} / \mathrm{lane})$ were performed with a standard method using $10 \%$ SDS-PAGE gels and polyvinylidene difluoride membranes (Bio-Rad). The following primary antibodies were used for detection with an ECL prime Western Blotting Detection System (GE Healthcare, Waukesha, WI, USA): anti-phosphospecific IkB-a (Ser32), anti-IкBa, anti-phospho-specific p44/42 MAPK (ERK1/2)(Thr201/ Tyr204), anti-phospho-specific SAPK/JNK(Thr183/tyr185), anti- $\beta$-Tubulin (all from Cell Signaling Technology, Danvers, MA, USA).

\subsection{Statistical Analysis}

Results are shown as mean \pm SEM. Two groups were compared using Student's t-test. Between-group comparison of means was performed by ANOVA, followed by t-test. A value of $p<0.05$ was regarded as statistically significant. 


\section{Results}

\subsection{APN suppresses TF expression in human MФ}

In human monocyte-derived MФ, LPS, but not APN alone (10 $\mu \mathrm{g} / \mathrm{ml})$, increased TF mRNA levels approximately fourfold, compared with controls (Fig. 1A). APN pretreatment, however, significantly inhibited the increased expression of TF in a concentration-dependent manner $(76.8 \%$ at $10 \mu \mathrm{g} / \mathrm{ml}$ of APN, p< 0.001 vs. LPS alone, n=4; Fig. 1A). Concordant with the suppression of mRNA levels, APN reduced the production of TF protein in a concentration-dependent manner (Fig. 1B).

\subsection{APN suppresses pro-coagulant activity in LPS-stimulated $М \Phi$}

Evaluation of the effect of APN on clot formation through TF used a one-step clotting assay with MФ cell lysates. LPS stimulation shortened coagulation half-max time, which represents TF activity on clot formation (no stimulation: $42.4 \pm 0.5$ minutes vs. LPS: $27.9 \pm 0.7$ minutes, $n=4$, $p<0.0001$; Fig. 2 ). APN pre-treatment, however, significantly extended the half-max time up to $37.3 \pm 0.4$ minutes at $10 \mu \mathrm{g} / \mathrm{ml}$ of APN (vs. LPS alone, $\mathrm{n}=4$, $\mathrm{p}<0.0001$ ), indicating APN suppression of pro-coagulant TF activity (Fig. 2).

\subsection{APN inhibits LPS-induced TF promoter activity}

To elucidate the mechanism by which APN exposure regulates the TF gene, we evaluated the effect of APN on TF transcription. We used a mouse MФ cell line (RAW 264.7) to optimize transfection efficiency with the TF promoter reporter construct (Fig. 3A). In these construct-transfected cells, LPS increased luciferase activity by $4.94 \pm 0.27$ times, compared with vehicle control (Fig. 3B). Adiponectin pre-incubation reduced LPS-induced increase in TF promoter activity by $76 \%(10 \mu \mathrm{g} / \mathrm{ml}$ of APN, $1.94 \pm 0.19$ times, $\mathrm{n}=4,<0.01$, Fig. 3B).

\subsection{APN suppresses the phosphorylation and degradation of IkB- $\alpha$ in $M \Phi$}

To evaluate the intracellular mechanism of APN on TF transcription, we performed immunoblot analysis with human MФ. In monocytes/MФ, LPS stimulation activates several signaling pathways distal to TLR4 - NF- $\mathrm{kB}$, JNK, and ERK1/2 - that facilitate the transcription of $\mathrm{TF}^{21,24}$. APN inhibits activation of NF- $\kappa \mathrm{B}$, but not of JNK or ERK1/2 signaling pathways, as shown by Western blot analysis. APN inhibited LPS-induced phosphorylation and degradation of I $\kappa \mathrm{B}-a$ that inhibits NF- $\kappa \mathrm{B}$ function (Fig. 4). APNinduced stabilization of I $\kappa \mathrm{B}-\mathrm{a}$ points to an important molecular mechanism for APN inhibition of NF- $\kappa$ B-regulated TF expression.

\section{Discussion}

Many mechanisms may contribute to heightened cardiovascular risk associated in some studies with hypoadiponectinemia. APN appears to regulate plaque inflammation and stability in particular, by functioning as an anti-inflammatory adipocytokine that reduces the production of inflammatory cytokines and chemokines, such as tumor necrosis factor alpha $(\mathrm{TNFa})$ and interferon-inducible protein 10 (IP-10) $)^{15,25}$. APN also increases expression of interleukin-10 (IL-10), a cytokine with anti-inflammatory properties, and of tissue inhibitor of matrix metalloproteinase-1 (TIMP-1) ${ }^{26}$. Moreover, APN increases high-density lipoprotein assembly in the liver that may subsequently remove cholesterol from atheromata ${ }^{27}$. These actions may stabilize plaques and reduce their size and risk of rupture.

TF produced by $М \Phi$, the most abundant inflammatory cells in atheromatous plaques, likely triggers many thrombotic complications of atherosclerosis. The present study shows that APN reduces LPS-stimulated expression of TF mRNA and protein by qRT-PCR, TF luciferase promoter, and ELISA experiments. In addition, one-step clotting assay 
experiments demonstrated that APN treatment significantly inhibits TF-dependent M $\Phi$ procoagulant activity.

Notably, an NF- $\kappa \mathrm{B}$ binding site exists in the promoter region of TF, and LPS directs NF- $\kappa \mathrm{B}$ activation by initiating Toll-like receptor 4-dependent phosphorylation/degradation of the NF- $\kappa B$ inhibitor $I \kappa B^{21}$. Mechanistic studies that examined APN regulation of LPSstimulated NF- $\kappa B$, JNK, and ERK1/2 intracellular signaling in M $\Phi$ showed that APN attenuates NF- $\kappa \mathrm{B}$ signaling by reducing the phosphorylation of I $\kappa \mathrm{B}-\mathrm{a}$. APN can also suppress the phosphorylation and subsequent degradation of I $\mathrm{kB}-\boldsymbol{a}$ in vascular endothelial cells $^{28}$. Our immunoblot analyses with MФ showed that APN treatment reduces the phosphorylation and degradation of I $\times B-a$ without affecting the activation of JNK and ERK1/2 signaling cascades. Thus, APN presumably suppresses NF- $\mathrm{kB}$ binding to the TF promoter region through the limitation of inflammatory signaling downstream of TLR4 in МФ.

Kato et al. reported that APN deficiency accelerates thrombus formation through the enhancement of platelet aggregation in mice ${ }^{29}$. Although their studies focused on platelet factors rather than coagulation factors, APN inhibition of TF might contribute to enhanced thrombosis in APN-deficient mice. Previous studies have shown that APN inhibits TF expression and enhances TF pathway inhibitor expression in human endothelial cells ${ }^{30}$. During atherogenesis, monocytes adhere to injured endothelial cells and invade subendothelial space, then accumulate lipids to become foam cells in fatty streaks and vulnerable plaques. The dominant source of TF in the arterial wall during this process, as a determinant of plaque thrombogenicity, gradually shifts from endothelial cells to inflammatory $\mathrm{M} \Phi$, an abundant cell type in advanced atheroma ${ }^{20}$. Indeed, LPS, used as a model pro-inflammatory stimulus in the present study, may not itself trigger thrombotic complications in most ACS. Thus, future studies in vitro and in vivo with this regard should address APN's modulatory effects on other putative atherogenic stimuli. Our finding that APN attenuates MФ TF expression, however, may provide in part a mechanistic basis for increased risk of atherothrombotic events in individuals with hypoadiponectinemia ${ }^{17,19}$.

Taken together, the results of our study suggest a mechanistic link between APN and the thrombotic complications of atherosclerosis (Fig. 5). Therapeutic interventions that elevate APN in CAD patients may not only prevent the progression of atheromatous plaques, but also may reduce atherothrombotic events by suppressing $\mathrm{M} \Phi \mathrm{TF}$ expression.

\section{Acknowledgments}

This study was supported in part by a grant from the Takeda Science Foundation (Y.O.) and by a grant from the U.S. National Heart, Lung, and Blood Institute (NHLBI) HL-080472 (P.L.)

\section{References}

1. Matsuzawa Y, Funahashi T, Nakamura T. The concept of metabolic syndrome: contribution of visceral fat accumulation and its molecular mechanism. J Atheroscler Thromb. 18:629-639. [PubMed: 21737960]

2. Libby P. Current concepts of the pathogenesis of the acute coronary syndromes. Circulation. 2001; 104:365-372. [PubMed: 11457759]

3. Okamoto Y, Kihara S, Funahashi T, et al. Adiponectin: a key adipocytokine in metabolic syndrome. Clin Sci (Lond). 2006; 110:267-278. [PubMed: 16464169]

4. Ouchi N, Kihara S, Arita Y, et al. Novel modulator for endothelial adhesion molecules: adipocytederived plasma protein adiponectin. Circulation. 1999; 100:2473-2476. [PubMed: 10604883] 
5. Zoccali C, Mallamaci F, Tripepi G, et al. Adiponectin, metabolic risk factors, and cardiovascular events among patients with end-stage renal disease. J Am Soc Nephrol. 2002; 13:134-141. [PubMed: 11752030]

6. Kumada M, Kihara S, Sumitsuji S, et al. Association of hypoadiponectinemia with coronary artery disease in men. Arterioscler Thromb Vasc Biol. 2003; 23:85-89. [PubMed: 12524229]

7. Pischon T, Girman CJ, Hotamisligil GS, et al. Plasma adiponectin levels and risk of myocardial infarction in men. JAMA. 2004; 291:1730-1737. [PubMed: 15082700]

8. Komura N, Kihara S, Sonoda M, et al. Clinical significance of high-molecular weight form of adiponectin in male patients with coronary artery disease. Circ J. 2008; 72:23-28. [PubMed: 18159094]

9. Sattar N, Wannamethee G, Sarwar N, et al. Adiponectin and coronary heart disease: a prospective study and meta-analysis. Circulation. 2006; 114:623-629. [PubMed: 16894037]

10. Sattar N, Watt P, Cherry L, et al. High molecular weight adiponectin is not associated with incident coronary heart disease in older women: a nested prospective case-control study. J Clin Endocrinol Metab. 2008; 93:1846-1849. [PubMed: 18303082]

11. Okamoto Y, Arita Y, Nishida M, et al. An adipocyte-derived plasma protein, adiponectin, adheres to injured vascular walls. Horm Metab Res. 2000; 32:47-50. [PubMed: 10741683]

12. Ouchi N, Kihara S, Arita Y, et al. Adipocyte-derived plasma protein, adiponectin, suppresses lipid accumulation and class A scavenger receptor expression in human monocyte-derived macrophages. Circulation. 2001; 103:1057-1063. [PubMed: 11222466]

13. Okamoto Y, Kihara S, Ouchi N, et al. Adiponectin reduces atherosclerosis in apolipoprotein Edeficient mice. Circulation. 2002; 106:2767-2770. [PubMed: 12451000]

14. Yamauchi T, Kamon J, Waki H, et al. Globular adiponectin protected ob/ob mice from diabetes and ApoE-deficient mice from atherosclerosis. J Biol Chem. 2003; 278:2461-2468. [PubMed: 12431986]

15. Okamoto Y, Folco EJ, Minami M, et al. Adiponectin inhibits the production of CXC receptor 3 chemokine ligands in macrophages and reduces T-lymphocyte recruitment in atherogenesis. Circ Res. 2008; 102:218-225. [PubMed: 17991878]

16. Nawrocki AR, Hofmann SM, Teupser D, et al. Lack of association between adiponectin levels and atherosclerosis in mice. Arterioscler Thromb Vasc Biol. 2010; 30:1159-1165. [PubMed: 20299691]

17. Otsuka F, Sugiyama S, Kojima S, et al. Plasma adiponectin levels are associated with coronary lesion complexity in men with coronary artery disease. J Am Coll Cardiol. 2006; 48:1155-1162. [PubMed: 16978998]

18. Wolk R, Berger P, Lennon RJ, et al. Association between plasma adiponectin levels and unstable coronary syndromes. Eur Heart J. 2007; 28:292-298. [PubMed: 17090613]

19. Nakagawa Y, Kishida K, Mazaki T, et al. Impact of sleep-disordered breathing, visceral fat accumulation and adiponectin levels in patients with night-time onset of acute coronary syndrome. Am J Cardiol. 108:1266-1271. [PubMed: 21840491]

20. Mackman N. Role of tissue factor in hemostasis, thrombosis, and vascular development. Arterioscler Thromb Vasc Biol. 2004; 24:1015-1022. [PubMed: 15117736]

21. Mackman N, Brand K, Edgington TS. Lipopolysaccharide-mediated transcriptional activation of the human tissue factor gene in THP-1 monocytic cells requires both activator protein 1 and nuclear factor kappa B binding sites. J Exp Med. 1991; 174:1517-1526. [PubMed: 1744583]

22. Marx N, Mach F, Sauty A, et al. Peroxisome proliferator-activated receptor-gamma activators inhibit IFN-gamma-induced expression of the T cell-active CXC chemokines IP-10, Mig, I-TAC in human endothelial cells. J Immunol. 2000; 164:6503-6508. [PubMed: 10843708]

23. Drake TA, Ruf W, Morrissey JH, et al. Functional tissue factor is entirely cell surface expressed on lipopolysaccharide-stimulated human blood monocytes and a constitutively tissue factorproducing neoplastic cell line. J Cell Biol. 1989; 109:389-395. [PubMed: 2663880]

24. Guha M, O'Connell MA, Pawlinski R, et al. Lipopolysaccharide activation of the MEK-ERK1/2 pathway in human monocytic cells mediates tissue factor and tumor necrosis factor alpha expression by inducing Elk-1 phosphorylation and Egr-1 expression. Blood. 2001; 98:1429-1439. [PubMed: 11520792] 
25. Yokota T, Oritani K, Takahashi I, et al. Adiponectin, a new member of the family of soluble defense collagens, negatively regulates the growth of myelomonocytic progenitors and the functions of macrophages. Blood. 2000; 96:1723-1732. [PubMed: 10961870]

26. Kumada M, Kihara S, Ouchi N, et al. Adiponectin specifically increased tissue inhibitor of metalloproteinase-1 through interleukin-10 expression in human macrophages. Circulation. 2004; 109:2046-2049. [PubMed: 15096450]

27. Matsuura F, Oku H, Koseki M, et al. Adiponectin accelerates reverse cholesterol transport by increasing high density lipoprotein assembly in the liver. Biochem Biophys Res Commun. 2007; 358:1091-1095. [PubMed: 17521614]

28. Ouchi N, Kihara S, Arita Y, et al. Adiponectin, an adipocyte-derived plasma protein, inhibits endothelial NF-kappaB signaling through a cAMP-dependent pathway. Circulation. 2000; 102:1296-1301. [PubMed: 10982546]

29. Kato H, Kashiwagi H, Shiraga M, et al. Adiponectin acts as an endogenous antithrombotic factor. Arterioscler Thromb Vasc Biol. 2006; 26:224-230. [PubMed: 16269667]

30. Chen YJ, Zhang LQ, Wang GP, et al. Adiponectin inhibits tissue factor expression and enhances tissue factor pathway inhibitor expression in human endothelial cells. Thromb Haemost. 2008; 100:291-300. [PubMed: 18690350] 


\section{Highlights}

Adiponectin suppresses tissue factor expression in LPS-stimulated macrophages (MФ).

Adiponectin reduces pro-coagulant activity in LPS-stimulated МФ.

The inhibitory mechanisms of tissue factor by adiponectin were studied.

The increment of adiponectin may prevent atherothromosis in coronay artery disease. 
A

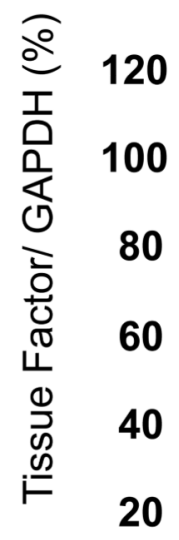

APN $(\mu \mathrm{g} / \mathrm{ml})$

0

10

$0 \quad 1$

3

10

B

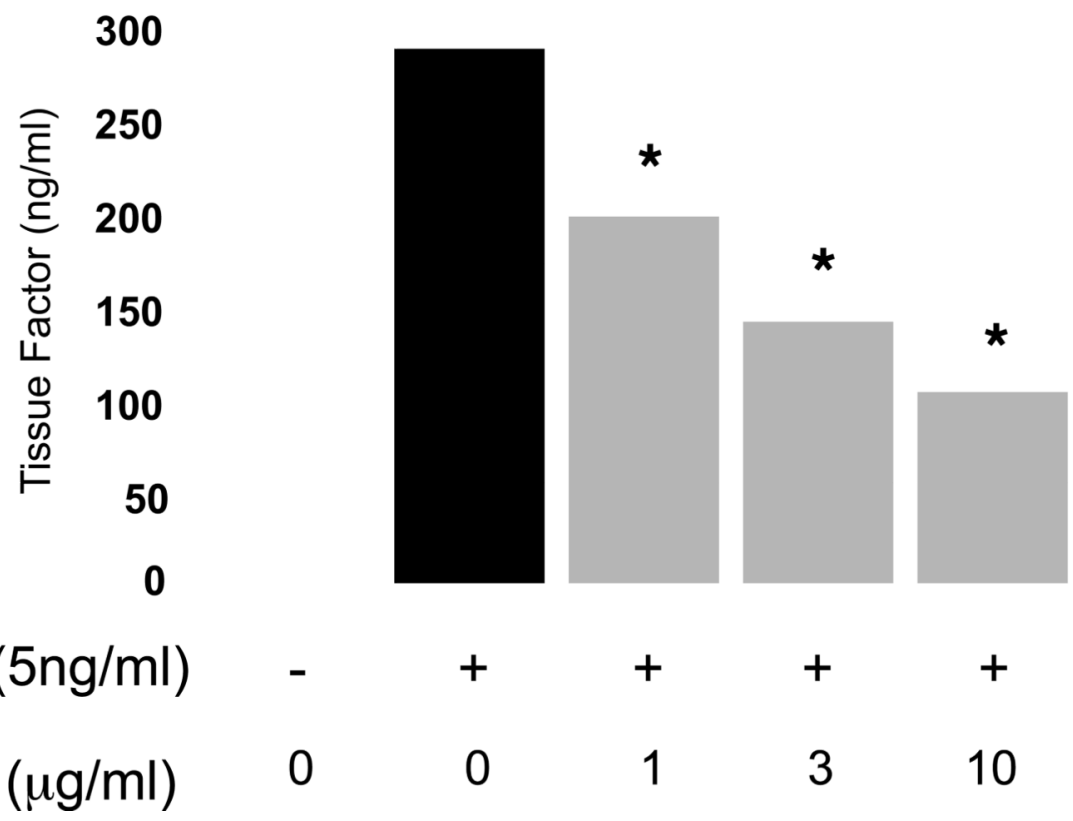

Fig. 1. APN suppresses TF gene expression and protein production in LPS-stimulated human МФ

Human monocyte-derived MФ (day 10) were treated with the indicated concentration of recombinant human APN in starvation media for 24 hours, and then stimulated with LPS (5 $\mathrm{ng} / \mathrm{ml}$ ) for 6 hours. (A) Gene expression of TF analyzed by real-time quantitative RT-PCR. mRNA levels of GAPDH served as an internal control for adjustment between samples. (B) TF protein in TF cell lysates assayed by ELISA. Data are expressed relative to the values of LPS-alone treatment $(100 \%)$ in mean $\pm \operatorname{SEM}(\mathrm{n}=4) .{ }^{*} p<0.001$ vs. LPS. 


\section{5 \\ One Step Clotting Assay}

40

$\stackrel{\mathscr{E}}{E} 35$

$\stackrel{\sqrt{\sigma}}{\check{2}}$

$\frac{4}{\pi}$

30

25
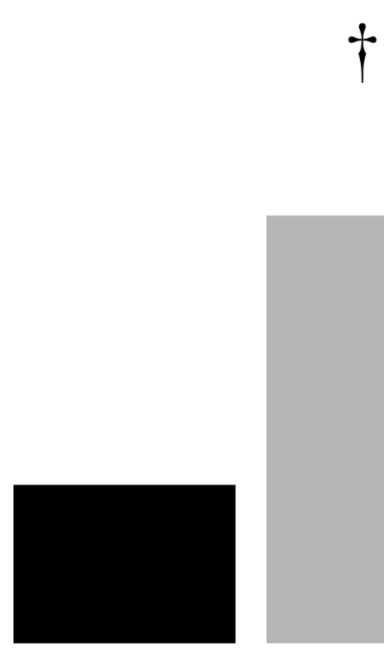

*
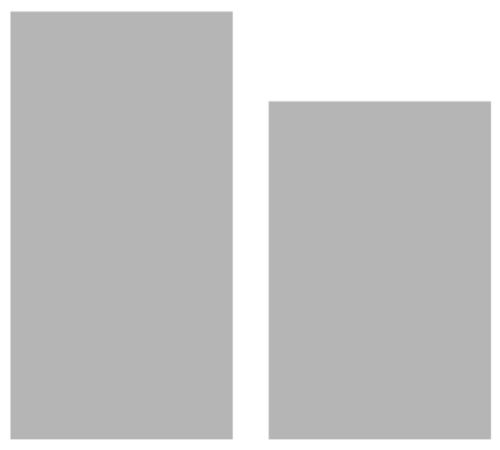

LPS $100 \mathrm{ng} / \mathrm{ml}$

$+$

$+$

$+$

$+$

APN $(\mu \mathrm{g} / \mathrm{ml})$

0

0

1

3

Fig. 2. APN reduces pro-coagulant activity initiated by TF in LPS-stimulated human MФ

A one-step clotting assay was performed with human $М \Phi$ lysates, treated as indicated. "Clot initiation time" was the time at which absorbance began to increase continuously. "Half-max time" was the time at which the absorbance reading reached half of the difference between initial and maximum absorbance. Data are expressed in mean "half-max time" \pm SEM $(n=4)$. $* p<0.001,{ }^{\dagger} p<0.0001$ vs. LPS. 

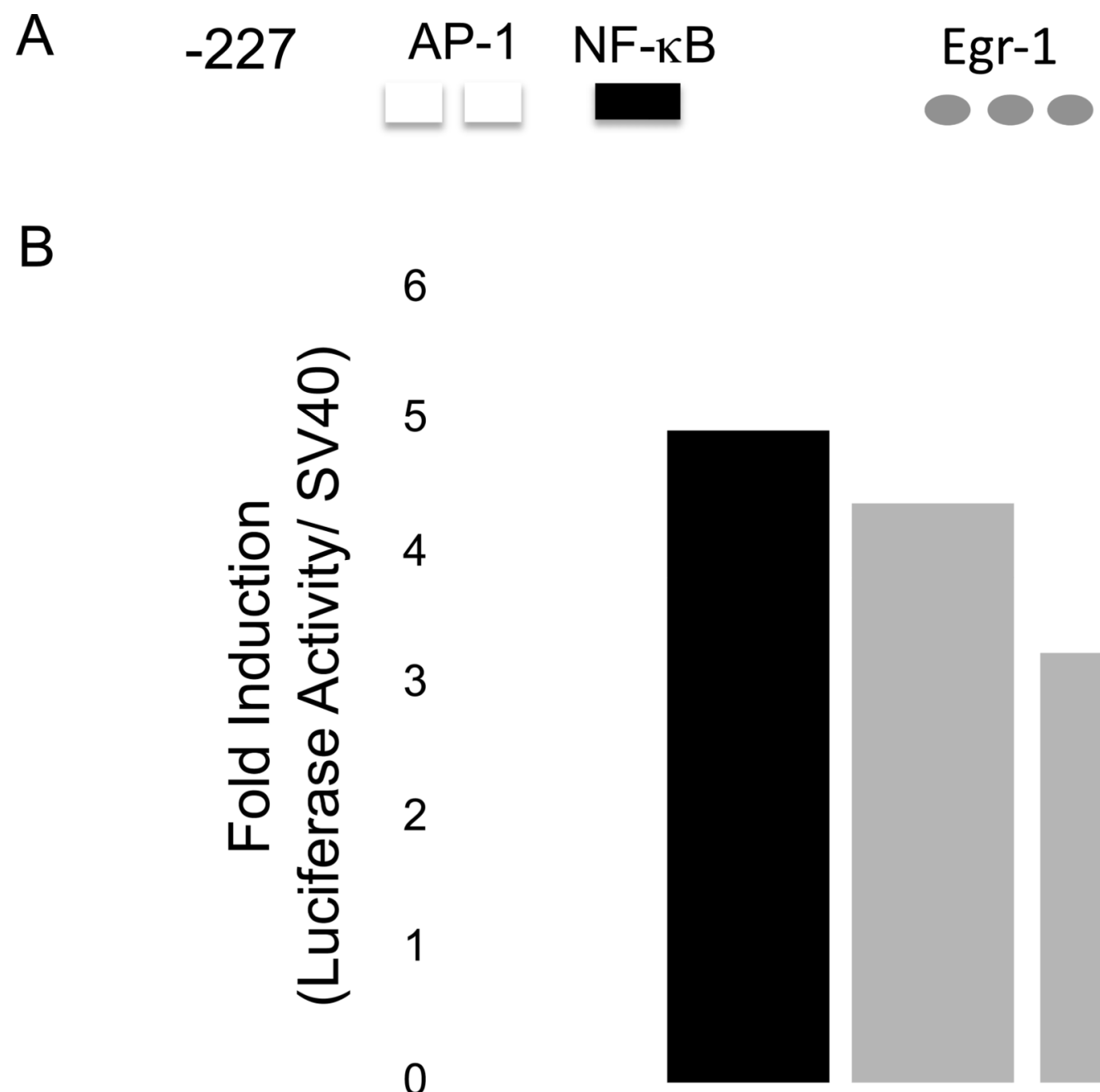

*

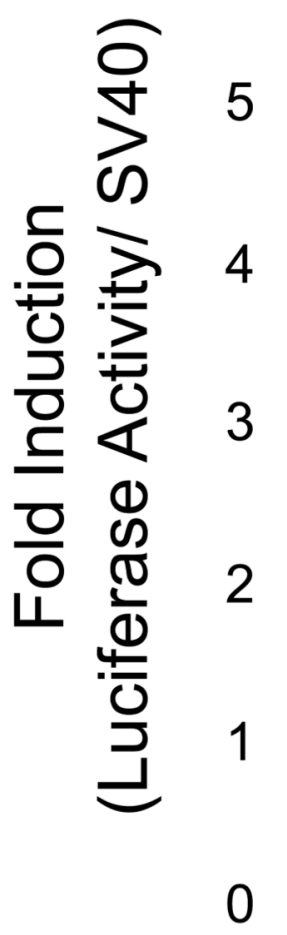

LPS (100ng/ml)

$+$

$+$

$+$

$+$

APN $(\mu \mathrm{g} / \mathrm{ml})$

0

0

1

3

10

Fig. 3. APN inhibits TF promoter activity in LPS-stimulated RAW 264.7 cells

TF promoter reporter construct-transfected RAW 264.7 cells were pre-treated with APN for 24 hours, and then stimulated with LPS $(100 \mathrm{ng} / \mathrm{ml})$ for 6 hours. The promoter activity in the harvested cells was determined by dual luciferase assay. SV40 indicates control vector (pRL-SV40) $(\mathrm{n}=4, * p<0.0001$ vs. LPS). 


\title{
$\mathrm{p}-\mathrm{I}_{\mathrm{K}} \mathrm{B}-\alpha$
}

$I \kappa B-\alpha$

p-JNK

p-ERK1/2

\author{
$\beta$-tubulin
}

\section{$\operatorname{APN}(10 \mu \mathrm{g} / \mathrm{ml})$}

LPS $(5 \mathrm{ng} / \mathrm{ml})$
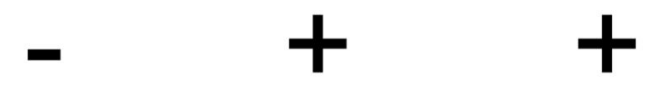

Fig. 4. APN attenuates LPS-triggered intracellular activation of $I x B-a$ responsible for TF transcription in human $\mathrm{M} \Phi$

Human МФ were incubated with or without (left lanes) $10 \mu \mathrm{g} / \mathrm{ml}$ of APN for 24 hours, and subsequently stimulated with $5 \mathrm{ng} / \mathrm{ml}$ of LPS for 15 minutes. Whole-cell lysates were fractionated by SDS-PAGE and immunoblotted with indicated antibodies. $\beta$-tubulin served as a loading control. 


\title{
Inflammatory Macrophage
}

\section{Adiponectin} Adipocyte

\author{
Intrinsic Pathway
}

\section{Tissue Factor $\downarrow \downarrow \downarrow$}
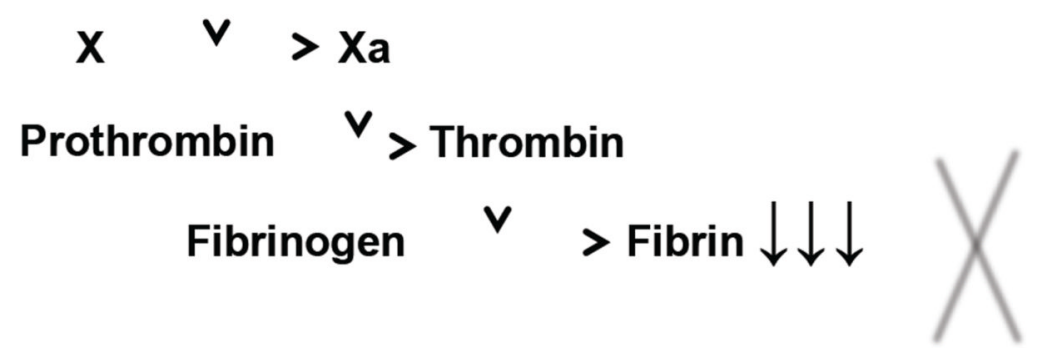

Atherothrombosis

Fig. 5. APN inhibits MФ TF in coagulation cascade, a potential mechanism in the prevention of atherothrombosis

APN secreted from adipocytes interacts with MФ in disrupted atheromatous plaques and inhibits TF production. It subsequently attenuates the activation of the coagulation cascade and arterial thrombus formation - a key pathology in atherothrombosis. 